九州大学学術情報リポジトリ

Kyushu University Institutional Repository

FAUNAL AND BIOLOGICAL STUDIES ON THE INSECTS OF PADDY FIELDS IN ASIA. PART II. ILLUSTRATED KEY TO THE THAI SPECIES OF PIPUNCULIDAE (DIPTERA)

Yano, Koj i

https://doi.org/10.5109/2386

出版情報 : ESAKIA. 13，pp.45-54，1979-03-10. Entomological Laboratory，Faculty of Agriculture， Kyushu University

バージョン :

権利関係 : 


\title{
FAUNAL AND BIOLOGICAL STUDIES ON THE INSECTS OF PADDY FIELDS IN ASIA. PART II. ILLUSTRATED KEY TO THE THAI SPECIES OF PIPUNCULIDAE (DIPTERA)*
}

\author{
KôJI YANO \\ Laboratory of Applied Entomology, Faculty of Agriculture \\ Yamaguti University, Yamaguti 753, Japan
}

\begin{abstract}
Keys to ten species of the Thai Pipunculidae from paddy fields are presented with illustrations of the most distinct and practical characters of each species. The materials are based on the collection made by a series of the field surveys from 1970 to 1977 . Six species among them are recorded here for the first time from the paddy fields of Thailand.
\end{abstract}

Pipunculid flies collected from paddy fields in Thailand have been scarcely recorded up to the present, although more than twenty species have been recorded from Thailand inclusive of any habitat. Those known paddy dwelling species of Thailand are Pipunculus(Eudorylas) javanensis de Meijere, P.(E.) orientalis (Koizumi), P. (E.) roralis (Kertész) and Tomosvaryella oryzaetora Koizumi (Hardy, 1972 a).

Through a series of field surveys which have been carrying on in S. E. Asia (Yasumatsu et al., 1975; Hirashima et al., 1979), the flies have been receiving much attention by the project because of its importance in relation to homopterous rice pests. Owing to the limited time and seasons allowed for the surveys, however, the collection of the Pipunculidae from paddy fields made in Thailand is not big at present. Eight species belonging to 3 genera have collected by the project. Among the species recorded by Hardy (1972 a), 2 species have not collected by the project. Total 10 species are known from Thai paddy fields now. Six species among them are recorded here for the first time from the paddy fields of Thailand.

The present paper is written to record the collections of the project and

\footnotetext{
* Partial result of Grants-in-Aid for Overseas Scientific Survey (1970, 1973, 1977) from the Ministry of Education, Science and Culture, Japanese Government (Principal investigator: Prof. K. Yasumatsu in 1970; Prof. Y. Hirashima in 1973 and 1977).

The printing cost of this paper is supported by grant No. 304329, the Ministry of Education, Science and Culture (Principal investigator : Prof. Y. Hirashima).
} 
for the practical purpose for applied entomologists concerned in identifying the known Pipunculid species dwelling in paddy fields in Thailand rather than a comprehensive paper on the flies of this habitat and area. It is easily supposed that the Thai fauna of this group in paddy fields may be more rich judging from the present knowledge on the latitudinal diversity of living organisms in the world. The present key is consequently a preliminary one. Review on the paddy field fauna of this family along the line mentioned before (Yano, 1978) will be given in elsewhere.

Before going further, I would like to express my sincere gratitude to Professor Y. Hirashima, Kyushu University, for his kindness in various ways for the present work. I am much indebted to Dr. K. Yasumatsu, Professor Emeritus of Kyushu University, for his critical suggestions to my work on paddy field insects. My hearty thanks are also due to Dr. T. Miura, Shimane University, and Dr. Tanongchit Wongsiri, Department of Agriculture, Thailand, who are kind enough to collect the valuable specimens and other ways.

\section{List of the species}

Specimens examined here are based on the materials collected by the project mentioned above. These specimens were collected by Drs. Y. Hirashima, T. Miura and myself who made sweepings rather extensively with a view to collect the flies. I made sweepings in July and August of 1970 and 1973, Drs. Hirashima and Miura made in October to December of 1977. From the limited survey and material, following notes which are of course tentative may be briefly mentioned.

No specimen of Pipunculus was collected in earlier seasons (July and August in this case), while 29 specimens of 3 species of the genus in later seasons (October to December in this case). Tomosvaryella sylvatica was much collected in earlier seasons, while only one in later. T. nitens, on the contrary, was much in later and few in earlier.

As all specimens were collected by sweepings from paddy fields, no indications about the habitat are mentioned in the data. Those collected from ridge of paddy fields are indicated as "ridge". The present materials include no rearing specimens from host insects. So the host record listed below is based on the published data. Locality names and other informations on the materials are referable to Yasumatsu et al., 1975 and Hirashima et al., 1979.

\section{Pipunculus (Eudorylas) mutillatus Loew, 1857}

Specimens examined:1 1 , Chainat, 12. xi. 1977, Y. Hirashima; $1 \gtrsim \mathbf{1}$ ㅇ, ditto, 18. xi. 1977, Y. Hirashima ; $3 ð ð 1$ 우, ditto, 18. xi. 1977, T. Miura ; 2833 우우, Kamphaeng Phet, 14. xi. 1977, Y. Hirashima; 1 , Thoen, 15. xi. 1977, Y. Hirashima;3ðљ, Tak, 16. xi. 1977, Y. Hirashima ; 1 f, ditto, 16. xi. 1977, T. Miura; 1 우, Kalasin, $80 \mathrm{~km}$ E of Khon Kaen, 29. xi. 1977, Y. Hirashima; 1 , $30 \mathrm{~km} \mathrm{~N}$ 
of Khon Kaen, 2. xii. 1977, Y. Hirashima ;1 1 오, Ubol Ratana, 6. xii. 1977, Y. Hirashima.

Distribution : Thailand*, Burma, India, Nepal, Philippines*, Sabah, Taiwan*, Japan*, Micronesia, Africa.

Hosts: Nephotettix cincticeps Uhler, N. nigropictus Stål, N. virescens Distant and Hecalus sp.

This widely distributed species is common in the Asian paddy fields, though it has not been recorded from the habitat of Thailand so far. It has recently recorded from the Philippine paddy by Chandra (1978) and I have collected it from there also (Yano, unpublished data).

2. Pipunculus (E.) javanensis de Meijere, 1907

Specimens examined $: 1 \precsim, 25 \mathrm{~km} \mathrm{~S}$ of Chainat, 7. xi. 1977, ridge, Y. Hirashima ; 1 후, Kamphaeng Phet, 14. xi. 1977, Y. Hirashima ;1, ditto, 14. xi. 1977, T. Miura; $1 \lesssim$, Thoen, 15. xi. 1977, Y. Hirashima.

Distribution : Thailand*, Laos, India, Philippines*, Java, Sabah*, Taiwan*, Japan*.

Host : Nephotettix cincticeps Uhler.

This species is also widespread in Asia, and is recorded from 5 countries so far as paddy field is concerned. It is less collected by the project than the preceding species though.

3. Pipunculus (E.) macropygus de Meijere, 1941

Specimens examined: 2 우, Phayuhakhiri, $30 \mathrm{~km} \mathrm{~N}$ of Chainat, 9. xi. 1977, Y. Hirashima ; 1 으, Kamphaeng Phet, 14. xi. 1977, T. Miura.

Distribution: Thailand*, Laos, Vietnam, Nepal, India, Java, Philippines, Bismarck Is., Taiwan.

Host: Unknown.

This is the first record of this species from the paddy field. According to the known distribution of this species, it may be found more from other paddy areas.

4. Pipunculus (E.) orientalis (Koizumi, 1959)

Distribution : Thailand*, Burma, India, Vietnam, Philippines, Bismarck Is., Taiwan*, Japan*.

Host : Nephotettix cincticeps Uhler.

This widely distributed species in Asia has not collected by the project from Thailand. However, Hardy (1972a) recorded the specimens collected from Thai paddy fields. In the paddy fields of Japan, this species is one of the most abundant ones.

5. Pipunculus (E.) roralis (Kertész, 1915)

Distribution : Thailand*, Laos, Vietnam, Philippines, Taiwan*.

* Locality where the paddy field material has recorded including the present one is shown with asterisk. 
Host : Nephotettix cincticeps Uhler.

This species has not collected by the project from Thailand. It is, however, known from the paddy fields of Taiwan and Thailand (Hardy, 1972 a).

6. Dorylomorpha lini Hardy, 1972

Specimen examined: 1 , Phayuhakhiri, $30 \mathrm{~km} \mathrm{~N}$ of Chainat, 9. xi. 1977, Y. Hirashima.

Distribution : Thailand*, Philippines, Taiwan*.

Host: Unknown.

This species seems to be apparently rare judging from the known record. It has been known only from the Philippines and Taiwan. This is the first record of the species from Thailand.

7. Tomosvaryella oryzaetora Koizumi, 1959

Specimens examined $: 3 \Varangle \ni$, Songquare $\mathrm{nr}$ Sanpatong, 11. vii. 1970, K. Yano;

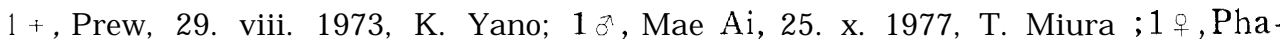
yuhakhiri, 9. xi. 1977, T. Miura ; 1 , Chainat, 12. xi. 1977, Y. Hirashima ; 1 年, Kamphaeng Phet, 14. xi. 1977, Y. Hirashima; 1 ; Tak, 16. xi. 1977, Y. Hirashima; $5 \precsim 1$ ㅇ, ditto, 16. xi. 1977, T. Miura; 1 , Udon Thani, 1. xii. 1977, T. Miura.

Distribution: Thailand*, Philippines*, Sabah*, Malaya*, India, Taiwan*, Japan*.

Hosts: Nephotettix cincticeps Uhler, N. nigropictus Stål and N.virescens Distant.

This well known paddy dwelling species was collected from Thailand in due course.

8. Tomosvaryella sylvatica (Meigen, 1824)

Specimens examined : 27 ॐ, Rangsit nr Bangkok, 6. viii. 1970, K. Yano; 1 , Udon Thani, 1. xii. 1977, T. Miura.

Distribution : Thailand*, Burma, Taiwan*, Japan*, Ussuri, Europe, N. Africa, N. America.

Hosts : Nephotettix cincticeps Uhler and Psamotettix striatus (Linné).

In spite of its wide distribution, this species is not major one among the paddy dwelling species in Asia so far as the surveys done before. However, 28 specimens were collected by the project mainly in earlier seasons. The latter host listed above, Psamotettix striatus, was recorded from URSS but not from the paddy field.

9. Tomosvaryella subvirescens (Loew, 1872)

Specimens examined : $3 \gtrsim \precsim$, Nakornrajsima, 4-5. viii. 1970, K. Yano; 1 우, Rangsit nr Bangkok, 6. viii. 1970, K. Yano; 1 , San Pa Tong, 14. viii. 1973, K. Yano ;123ð, ditto, 17. viii. 1973, K. Yano ; 1 우,Lamphun, 6. x. 1977, T. Miura ; 1 2 2 으, Mae Ai, 25. x. 1977, T. Miura ;9 8 , Phayuhakhiri, $30 \mathrm{~km} \mathrm{~N}$ of Chainat, 9. xi. 1977, Y. Hirashima; 481 우, ditto, 9. xi. 1977, T. Miura ; 1 q, Khanu Woralaksaburi, 9. xi. 1977, T. Miura; 2835 우, Chainat, 12. xi. 1977, 
Y. Hirashima ; 1 ㅇ, ditto, 18. xi. 1977, Y. Hirashima; 2 와, ditto, 18. xi. 1977, T. Miura ; $1 \precsim 2$ 우, Ban Mae Chung Rai, 15. xi. 1977, T. Miura ; $1 \lesssim 2 q q$, Thoen, 15. xi. 1977, Y. Hirashima ; 11 우, ditto, 15. xi. 1977, T. Miura ;3 3 , Tak, 16.

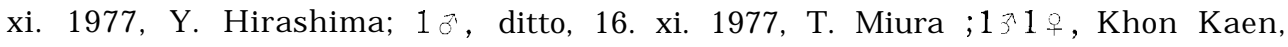
29. xi. 1977, Y. Hirashima ; 1 q, Udon Thani, 1. xii. 1977, T. Miura ; 1 , $30 \mathrm{~km} \mathrm{~N}$ of Khon Kaen, 2. xii. 1977, Y. Hirashima, 11 우, Hing Kong, 2. xii. 1977, T. Miura.

Distribution : Thailand*, Laos, India, Philippines*, Taiwan*, Micronesia, N. C. \& S. America, Africa.

Hosts: Nephotettix cincticeps Uhler, N. nigropictus Stal and N. virescens Distant.

This cosmopolitan species seems to be the most common one in the paddy fields of Thailand so far as the present data show, though it has not been recorded from the habitat of Thailand. Male genitalia of this species and the following species, nitens, are mentioned as nearly symmetrical in dorsal view in the present key. It should be noted, however, that it is so in outline only and not when the details are involved as shown in figures. The females of these two species have scarcely been figured or described.

10. Tomosvaryella nitens (Brunetti, 1912)

Specimens examined: 233 , San Pa Tong, 17. viii. 1973, K. Yano;3 38, Mae Ai, 25. x. 1977, T. Miura; $28 \%$, Khanu Woralaksaburi, $105 \mathrm{~km} \mathrm{~N}$ of Chainat, 9. xi. 1977, Y. Hirashima ; $3 \precsim$, ditto, 9. xi. 1977, T. Miura ;5 $5 \precsim$, Phayuhakhiri, $30 \mathrm{~km} \mathrm{~N}$ of Chainat, 9. xi. 1977, Y. Hirashima; 1 , Chainat, 12. xi. 1977, Y. Hirashima ; 13 , ditto, 18. xi. 1977, Y. Hirashima; 233 , Kamphaeng Phet, 14. xi. 1977, Y. Hirashima; $3 \gtrsim$, Thoen, 15. xi. 1977, Y. Hirashima; 13 , ditto, 15. xi. 1977, T. Miura ;2 2 , Tak, 16. xi. 1977, Y. Hirashima; 2 3 , ditto, 16. xi. 1977, T. Miura.

Distribution: Thailand*, India, Nepal.

Host : Unknown.

As the identification of this species is not certain (cf. Hardy, 1966, 1972 b), the present treatment should be a preliminary one. Rather many specimens were collected by the project.

\section{Illustrated key to the species}

Both sexes of the Pipunculid species treated here are easily separated by the head characters which show conspicuous shape composed almost entirely of compound eyes, and by the shape of caudal end of abdomen. The eyes of males are holoptic, meeting together for at least a short distance on the frons as shown in Figs. 1 and 2, and those of females are dichoptic, separating each other as shown in Fig. 4. Dorylomorphalini, however, has different eyes. Both eyes of males of this species are approaching but not meeting together as shown in Fig. 3. Besides the characters mentioned above, there 

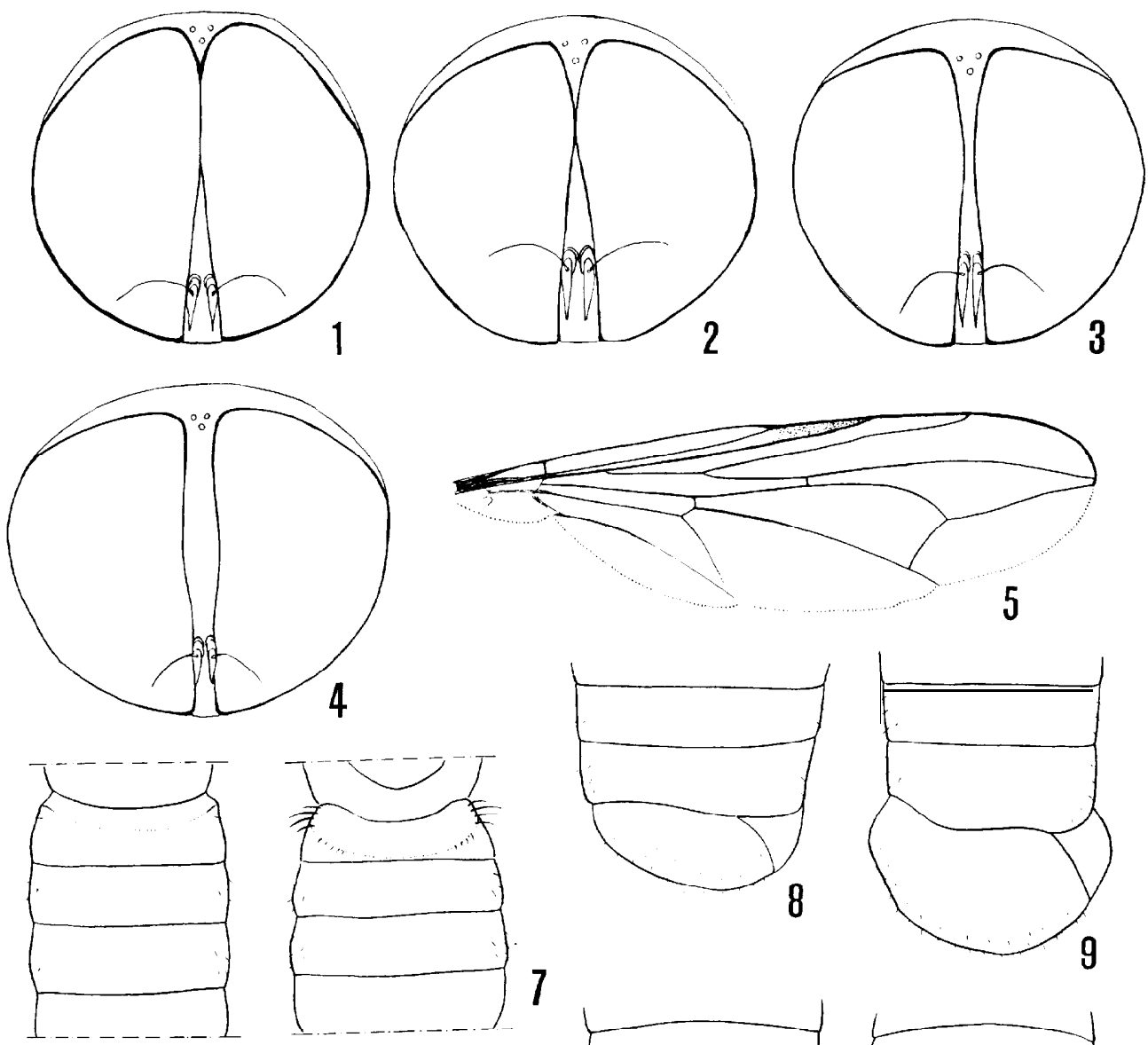

6
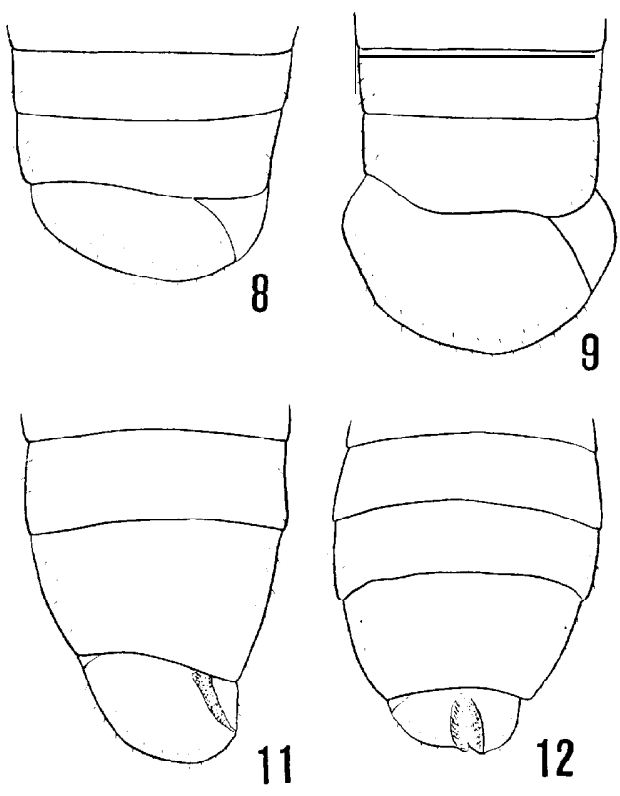

Figs. I-4. Head, anterodorsal view. 1: Pipunculus (Eudorylas) mutillatus, male. 2 :Tomosvaryella oryzaetora, male. 3: Dorylomorpha lini, male. 4: P. (E.) mutillatus, female,

Fig. 5, P. (E.) mutillatus, male, wing.

Figs. 6 and 7. Anterior part of abdomen, dorsal view. 6: P. (E.) macropygus, female. 7 : P. (E.) mutillatus, male.

Figs. 8-12. Caudal end of abdomen, male, dorsal view. 8: P. (E.) roralis. 9: P. (E.) macropygus. 10: P. (E.) javanensis, 11: P. (E.) mutillatus. 13: P. (E.) orientalis. 

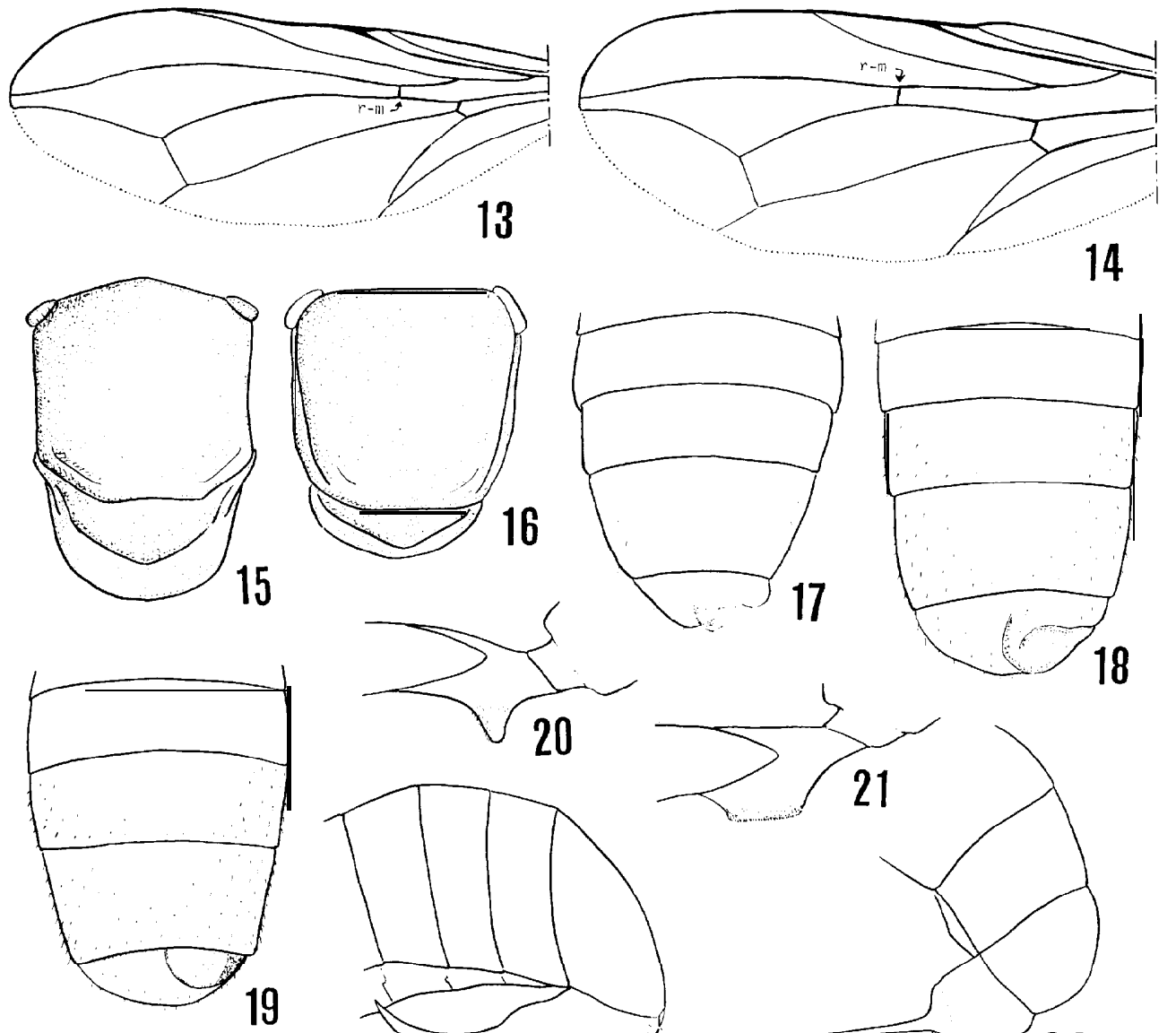

18

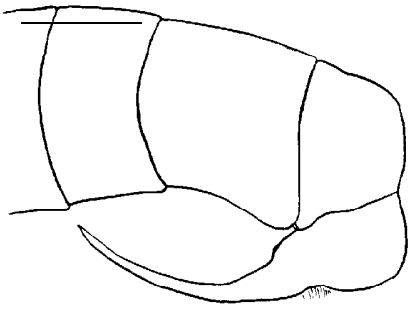

22

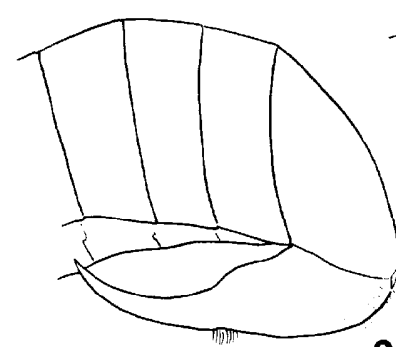

23

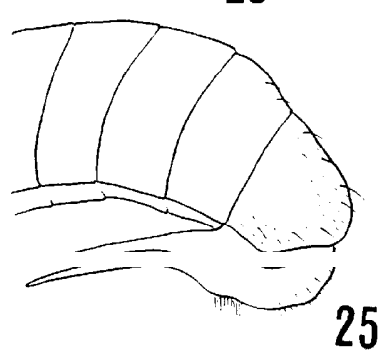

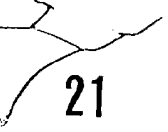
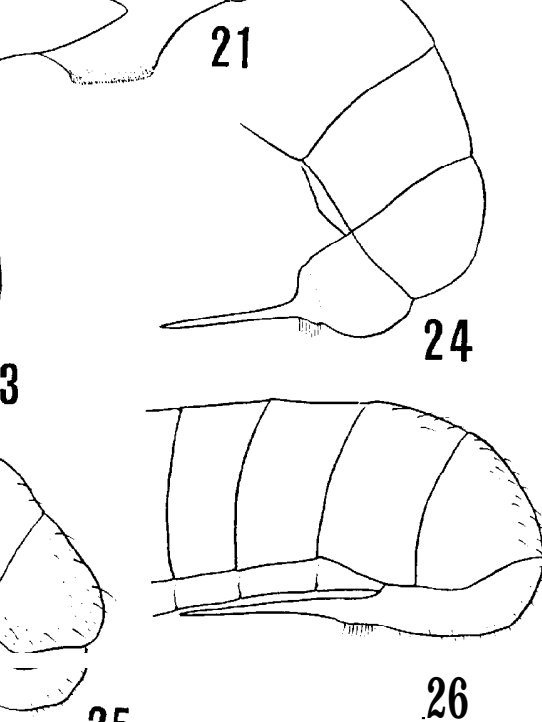

Figs. 13 and 14. Wing, male. 13: Dorylomorpha lini. 14: Tomosvaryella oryzaetora,

Figs. 15 and 16. Thorax, dorsal view. 15: T. oryzaetora, male. 16: T. subvirescens, male.

Figs. 17-19. Caudal end of abdomen, male, dorsal view. 17: T. sylvatica. 18: T. subvirescens. 19: T. nitens.

Figs. 20 and 21. Hind trochanter, male. 20: T. nitens. 21: T. subvirescens.

Figs. 22-26. Caudal end of abdomen, female, lateral view, 22: P. (E.) mutillatus, 23: P. (E.) javanensis. 24: P. (E.) orientalis. 25: T. sylvatica. 26: T. subvirescens. 
is a minor character of eyes separating both sexes. The median ommatidia in females are larger than those of other parts, while in males there is no difference. Caudal end of abdomen in this family is the most convenient character separating both sexes because of its quite different shape. It displays especially usefulness when head is fallen off from the body as it is seen very often in this family. Females, especially in allied species, resemble each other in this family. When we were involved with unknown paddy dwelling species besides the present ones, it should be careful to key out.

The following keys are based on the most distinct or convenient superficial characters rather than a set of the available characters for more practical use in applied field. Other characters which are also important for identification are daringly omitted from the keys and illustrations for the present purpose.

\section{ALES}

1. Wings with stigma (Fig. 5)

Pipunculus (E udorylas) 2

Wings without stigma

P. Abdomen without prominent setae on the sides of first tergum (Fig. 6) ; male genitalia nearly rounded, without a membranous area (Figs. 8 and 9)

Abdomen with a row of prominent setae on the sides of first tergum (Fig. 7); male genitalia with a membranous area (Figs. 10-12), but not seen in dorsal view in javanensis (Fig. 10)

3. Male genitalia not wider than fifth abdominal segment and almost equal length to that segment (Fig. 8)

P. (E.) roralis

Male genitalia wider than fifth abdominal segment, and apparently longer than that segment (Fig. 9) …............................................ macropygus

4. Male genitalia with a conspicuous membranous area but situated at its caudal end directed caudally or caudo-ventrally, and it is usually not seen in dorsal view (Fig. 10)

P. (E.) javanensis

Male genitalia with a narrow or wide longitudinal cleft, almost bisecting the

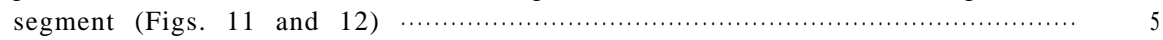

5. Male genitalia with a narrow, slit-like cleft on right side of dorsum (Fig. 11)

Male genitalia with a rather broad cleft on dorsum (Fig. 12) …...... P. (E.) orientalis

6. Wings with crossvein $\mathrm{r}-\mathrm{m}$ situated towards base at about one sixth of cell $1 \mathrm{st}$ $\mathrm{M}_{2}$ (discal cell)(Fig. $13 \mathrm{j}$ Dorylomorpha lini

Wings with crossvein $\mathrm{r}-\mathrm{m}$ situated at or about middle of cell $1 \mathrm{st} \mathbf{M}_{2}$ (discal cell) (Fig. 14)

7. Humeri black (Fig. 15) ; wings tinged with brown. T. oryzaetora

Humeri not black, but yellowish white (Fig. 16) ; wings hyaline, but slightly tinged with brown in nitens

8. Male genitalia asymmetrical in dorsal view (Fig. 17)

Male genitalia nearly symmetrical in dorsal view in outline (Figs. 18 and 19)
Hind trochanter with a prominent process (Fig. 20) ; male genitalia with ninth segment usually narrowly visible in ventral view T. nitens

Hind trochanter trapezoid (Fig. 21) ; male genitalia with ninth segment broadly visible in ventral view and distinctly shiny T. subvirescens 


\section{FEMALES}

1. Wings with stigma (Fig. 5)

Pipunculus (Eudorylas) ….. 2

Wings without stigma

Dorylomorpha, Tomosvaryella $\cdots \cdots . . .5$

2. Abdomen without prominent setae on the sides of first tergum (Fig. 6)

Abdomen with a row of prominent setae on the sides of first tergum (Fig. 7) ........ 3

3. Ovipositor with piercer distinctly upcurved (Figs. 22 and 23)

Ovipositor with piercer slender and almost straight (Fig. 24)

P. (E.) orientalis

4. Third segment of antennae light, pale yellowish brown; legs yellowish except for the most part of femora and distal end of tarsi; ovipositor as Fig. 22

P. (E.) mutillatus

Third segment of antennae not light, but dark brownish; legs blackish with some yellowish parts especially in tibiae and tarsi; ovipositor as Fig. 23

P. (E.) javanensis

5. Wings with crossvein $r-m$ situated towards base at about one sixth of cell $1 \mathrm{st}$

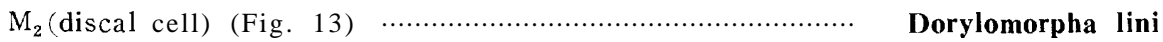
Wings with crossvein $\mathrm{r}-\mathrm{m}$ situated at or about middle of cell $1 \mathrm{st} \mathrm{M}_{2}$ (discal cell) (Fig. 14)

6. Humeri black (Fig. 15) ; wings tinged with brown

T. oryzaetora

Humeri not black, but yellowish white (Fig. 16) ; wings hyaline, but scarcely

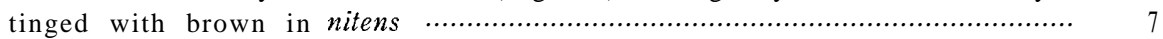

7. Hind trochanter trapezoid or with a prominent process ................................... 8

Hind trochanter not so; ovipositor with piercer downcurved (Fig. 25)

T. sylvatica

8. Hind trochanter with a prominent process (Fig. 20)

T. nitens

Hind trochanter trapezoid (Fig. 21); ovipositor with piercer nearly straight

(Fig. 26)

T. subvirescens

\section{References}

Int. Rice Res. Newsletter 3(5):20-21.

Hardy, D. E. 1966. Diptera from Nepal. Pipunculidae (Dorilaidae). Bull. Brit. Mus. (N. H.), 17(10): $439-449$.

Hardy, D. E. 1968 .

417--507.

Bismarck Islands.

Pipunculidae (Diptera) parasitic on rice leafhoppers in the Oriental

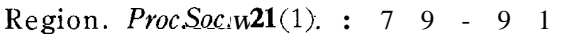

Hardy, D. E. 1972 b. Studies on Oriental Pipunculidae (Diptera). Oriental Insects Supplement No. 2, pp. 1-76.

Hardy, D. E. 1975. Family Pipunculidae. In : A catalog of Diptera of the Oriental Region. II. Delfinado, M. D. and D. E. Hardy, eds., University Press of Hawaii, pp. 296-306.

Hirashima, Y., K. Aizawa, T. Miura and T. Wongsiri 1979. Field studies on the biological control of leafhoppers and planthoppers (Hemiptera: Homoptera) injurious to rice

1. Females of these two species are closely allied superficially. The characters could be used for practical purpose here are not available. Those described by Hardy (1968) are delicate for the present purpose. 
plants in South-East Asia. Progress report for the year 1977. Esakia (13) : I-20, 1 pl. Koizumi, K. 1959. On four Dorilaid parasites of the green rice leafhopper, Nephotettix cincticeps Uhler (Diptera). Sci. Rept.Fac. Agric. Okayama Univ. 13: 37-46.

Koizumi, K. 1960. A new Dorilaid parasite of the zigzag-striped leafhopper, Inazumadorsalis (Motschulsky) and notes on other paddy-field inhabiting Dorilaidae (Diptera). Sci. Rept.Fac. Agric. O kayama Univ. 16: 33-42.

Yano, K. 1978. Faunal and biological studies on the insects of paddy fields in Asia. Part I. Introduction and Sciomyzidae from Asia (Diptera). Esakia (11) : I-27.

Yasumatsu, K., Y. Hirashima and K. Yano 1975. Field surveys on the biological control of insect pests and mites in S. E. Asia. General report. Mushi 48(10): 955123. 